\title{
Pengembangan kompetensi dalam menunjang tugas pokok dan fungsi aparatur pemerintah pada badan koordinasi wilayah pemerintahan dan pembangunan
}

\section{Development of competence in supporting main responsibility and function of government officers in area of development and governance coordination body}

\author{
Achmad Resa Fachrizi \\ Program Studi Pengembangan Sumber Daya Manusia, Program Pascasarjana Universitas \\ Airlangga, Surabaya \\ Jalan Airlangga 4-6 Surabaya, 60286, Indonesia \\ E-mail: fachrizi_conk@yahoo.com
}

\begin{abstract}
Work target for Regional Coordinating Bodies (Badan Koordinasi Wilayah/Bakorwil) is not generally realized as it targeted. As an institution with main duties in government development program in the area, there is a strong need to increase Bakorwil Pamekasan personal competence. This article analyzes to what extent officer competence development in Bakorwil Pamekasan and to review factors that influence officer competence development. This research method used was descriptive qualitative. The sample was collected by purposive sampling technique. In this research, Head of Bakorwil Pamekasan, Secretary of Bakorwil, and all the head division in Bakorwil were choosen as informant. Findings show that competency development in Bakorwil had not yet entirely implemented. There are several factors that hinder the competency development, namely: trust and value, skill/expertness, experiences, personal characteristics, motivation, emotional issues and intellectual capacity. This research concludes that the competency development program was still limited to work meeting, technical meeting, congress, seminar, technical guidance, and workshop. Officer's knowledge about their responsibility and work programs were limited. Moreover, further understanding for work program implementation was not yet fully understood.
\end{abstract}

Keywords: competence, employee, government, main responsibility, governance

\begin{abstract}
Abstrak
Sasaran kerja pegawai Bakorwil Pamekasan tidak semuanya dapat terealisasi sesuai target. Kompetensi personil Bakorwil Pamekasan masih perlu ditingkatkan, mengingat Bakorwil Pamekasan merupakan instansi yang memiliki tugas pokok dalam mengkoordinasikan pelaksanaan pembangunan pemerintah di daerah. Artikel ini menganalisis sejauh mana pengembangan kompetensi pegawai Bakorwil Pamekasan serta mengkaji faktorfaktor yang mempengaruhi pengembangan kompetensi pegawai. Metode penelitian yang digunakan dalam penelitian adalah jenis penelitian kualitatif deskriptif. Teknik pengambilan sampel yang digunakan dalam penelitian ini adalah purposive sampling, dalam penelitian ini yang dijadikan informan adalah Kepala Bakorwil Pamekasan, Sekretaris Bakorwil Pamekasan serta seluruh Kepala Bidang yang ada di Bakorwil Pamekasan. Temuan di lapangan menunjukkan bahwa pengembangan kompetensi yang dilakukan Bakorwil Pamekasan terhadap personilnya masih belum maksimal. Hal ini disebabkan oleh beberapa faktor yang menghambat pengembangan kompetensi personil, antara lain: kepercayaan dan nilai, keahlian, pengalaman, karakteristik personal, motivasi, isu-isu emosional dan kapasitas intelektual. Kesimpulan dalam penelitian bahwa pengembangan kompetensi yang dilakukan terhadap personil Bakorwil Pamekasan sebatas pada mengikuti rapat kerja, rapat teknis, kongres, seminar, bimbingan teknis dan workshop. Pengetahuan (knowledge) minimal personil Bakorwil Pamekasan yang berkaitan dengan tupoksi, program kerja dan tahapan-tahapan dalam melaksanakan program kerja tidak semua personil memahaminya.
\end{abstract}

Kata kunci: kompetensi, pegawai, pemerintah, tugas pokok, pemerintahan 


\section{Pendahuluan}

Sumber Daya Manusia (SDM) merupakan elemen terpenting bagi organisasi, berperan sebagai penggerak utama dalam mewujudkan visi dan misi serta tujuan organisasi. Mengingat begitu pentingnya SDM sesuai dengan kompetensi masing-masing, maka manajemen SDM diperlukan untuk mengelolanya secara sistematis, terencana dan terpola agar tujuan yang diinginkan organisasi pada saat sekarang maupun yang akan datang dapat tercapai secara optimal. Karena keberhasilan sebuah organisasi sangat ditentukan oleh orang-orang atau SDM yang bekerja di dalamnya. SDM yang dimaksud dalam kajian ini tidak lain adalah Aparatur Sipil Negara Bakorwil Pamekasan.

Terselenggaranya pemerintahan daerah yang baik dapat ditentukan dengan kualitas sumber daya aparaturnya. Kualitas sumber daya aparatur tersebut tentu perlu didukung oleh sistem manajemen sumber daya manusia yang berbasis kompetensi. SDM yang berkompeten adalah SDM yang mempunyai kemampuan, keterampilan dan sikap yang diperlukan dalam pelaksanaan tugas jabatannya sehingga aparatur tersebut dapat melaksanakan tugasnya secara efektif dan efisien. Pengelolaan manajemen aparatur pemerintah berbasis kompetensi adalah pengelolaan pegawai yang dilakukan atas dasar kompetensi yang dimilikinya, sehingga organisasi secara efektif dapat menempatkan orang yang tepat pada satu posisi pekerjaan tertentu dalam rangka mendukung strategi untuk mewujudkan visi misi instansi.

Dalam perkembangan kehidupan bernegara di era reformasi birokrasi sekarang ini, segenap komponen bangsa terpacu untuk memperbaiki dan mengembangkan sistem, tata kerja dan upayaupaya lainnya ke arah yang lebih baik. Demikian pula dengan dorongan untuk melakukan upaya sistematis dalam rangka lebih mendayagunakan aparatur negara guna mewujudkan masyarakat madani yang menjadi cita-cita segenap rakyat Indonesia. Untuk mencapai itu semua sudah tentu dibutuhkan aparatur negara yang profesional, yang tercermin dari sikap dan perilaku yang penuh kesetiaan, ketaatan, disiplin, bermoral, bermental baik, akuntabel dan memiliki kesadaran yang tinggi terhadap tanggung jawab sebagai pelayan publik yang baik.

Maka dari itu, perlu adanya reformasi birokrasi melalui pembinaan dan peningkatan kinerja individu. Peningkatan kemampuan kerja dilakukan dengan upaya peningkatan aspek-aspek yang mendasari unsur tersebut yakni pengetahuan dan keterampilan serta peningkatan motivasi kerja dengan cara membina mental individu dan situasi atau lingkungan yang mendorong timbulnya kemauan kerja individu. Sejalan dengan upaya mereformasi birokrasi, telah direspon oleh Pemerintah termasuk Pemerintah Provinsi Jawa Timur yang bisa dilihat dalam salah satu dari sembilan agenda dalam Rencana Pembangunan Jangka Menengah Daerah (RPJMD) Pemerintah Propinsi Jawa Timur yaitu agenda mewujudkan percepatan reformasi birokrasi dan meningkatkan pelayanan publik.

Oleh karena itu menurut Keith Davis dalam Emmyah (2009), menjelaskan bahwa ada dua faktor utama yang mempengaruhi kinerja individu yakni kemampuan (ability) dan motivasi kerja (motivation). Kemampuan individual tergantung dari tingkat pengetahuan (knowledge) yang dimiliki, latar belakang pendidikan dan keterampilan ( skill) yang dikuasai.

Dalam pelaksanaan tugas pokok dan fungsi Badan Koordinasi Wilayah Pamekasan, maka dukungan kualitas sumber daya aparatur menjadi sebuah keharusan. Kualitas sumber daya manusia merupakan salah satu faktor untuk meningkatkan produktivitas kinerja suatu instansi atau organisasi. Oleh karena itu diperlukan sumber daya manusia yang memiliki kompetensi tinggi sebagai bentuk dukungan peningkatan prestasi kinerja pegawai. Selama ini masih banyak instansi pemerintah yang belum memiliki pegawai dengan kompetensi yang memadai, hal ini dibuktikan dengan rendahnya produktivitas pegawai dan sulitnya mengukur kinerja pegawai pada lingkup instansi pemerintah.

Dengan memperhatikan tugas yang diemban, seharusnya Bakorwil menjadi ujung tombak Pemerintah Provinsi Jawa Timur di wilayahnya masing-masing dalam mengkoordinasikan pelaksanaan pembangunan di daerah sekaligus pembinaannya serta mampu merumuskan kebijakan-kebijakan 
teknis sebagai rekomendasi bahan masukan perumusan kebijakan Gubernur Jawa Timur terhadap kondisi yang berkembang di daerah.

Untuk mencapai kinerja yang efektif khususnya dengan melihat tugas pokoknya yang kompleks terutama dalam kaitan otonomi daerah di mana Pemerintah Kabupaten/Kota memiliki kewenangan untuk mengatur rumah tangga sendiri, maka Bakorwil harus didukung oleh setidaknya 4 (empat) aspek penting, yaitu: (1) kewenangan yang memadai; (2) aparatur yang memiliki kemampuan manajerial dan kemampuan teknis mumpuni; (3) manajemen kinerja yang baik; (4) sumber daya yang memadai termasuk dana, material, peralatan, teknologi dan lain sebagainya.

Berdasarkan Sasaran Kerja Pegawai (SKP) Bakorwil Pamekasan tahun 2014 bahwa belum sepenuhnya sasaran kerja tersebut dapat direalisasikan, hal ini juga dibuktikan dengan penelitian sebelumnya yakni pada realitasnya kinerja Bakorwil Pamekasan sampai saat ini masih belum menunjukkan kinerja seperti yang diharapkan, disebabkan oleh keterbatasan-keterbatasan sumber daya yang dimiliki, baik sumber daya manusia, sarana dan prasarana, kewenangan dan sebagainya.

Tujuan penelitian ini adalah menganalisa sejauh mana pengembangan kompetensi pegawai Badan Koordinasi Wilayah Pemerintahan dan Pembangunan Pamekasan kedua, penelitian ini bertujuan mengkaji faktor-faktor yang mempengaruhi pengembangan kompetensi pegawai dalam menunjang tugas pokok dan fungsi Badan Koordinasi Wilayah Pemerintahan dan Pembangunan Pamekasan.

Berdasarkan latar belakang dan masalah yang terkait dengan rendahnya kualitas pegawai yang memiliki kompetensi sesuai dengan bidang tugasnya, maka peneliti dapat mengidentifikasi masalah yaitu bagaimana pengembangan kompetensi pegawai dalam menunjang tugas, pokok dan fungsi pada Badan Koordinasi Wilayah Pemerintahan dan Pembangunan Pamekasan? serta faktor-faktor apa yang mempengaruhi pengembangan kompetensi pegawai dalam menunjang tugas, pokok dan fungsi Badan Koordinasi Wilayah Pemerintahan dan Pembangunan Pamekasan?

Menurut Muhyi (2009) pada realitasnya kinerja Bakorwil Pamekasan sampai saat ini masih belum menunjukkan kinerja seperti yang diharapkan, disebabkan oleh keterbatasan-keterbatasan sumber daya yang dimiliki, baik sumber daya manusia, sarana dan prasarana, kewenangan dan sebagainya. Saat ini sumber daya aparatur di Bakorwil Pamekasan, terdapat 49 orang Pegawai Negeri Sipil, sedangkan berdasarkan hasil analisis jabatan dan analisis beban kerja yang dilakukan seharusnya terdapat 69 orang Pegawai Negeri Sipil. Jika dilihat secara kualitatif dalam arti kualitas pegawai yang memiliki kompetensi sesuai dengan bidang tugasnya, tidak lebih dari $30 \%$. Selain itu sarana dan prasarana yang masih kurang memadai serta finansial untuk mengimplementasikan tugas pokoknya tidak mencukupi.

\section{Metode Penelitian}

Jenis penelitian yang digunakan dalam penelitian adalah jenis penelitian kualitatif deskriptif yaitu memberikan gambaran mengenai suatu fenomena tertentu secara terperinci untuk memahami secara lebih jelas suatu fenomena yang ada. Dalam penelitian ini peneliti berusaha menggambarkan bagaimana pengembangan kompetensi pegawai dan faktor-faktor apa yang mempengaruhi pengembangan kompetensi pegawai dalam menunjang tugas, pokok dan fungsi Badan Koordinasi Wilayah Pamekasan.

Dalam penelitian ini yang dijadikan informan adalah Kepala Bakorwil Pamekasan, Sekretaris Bakorwil Pamekasan serta seluruh Kepala Bidang (Kabid) yang ada di Bakorwil pamekasan. Alasan peneliti memilih sampel tersebut karena peneliti menganggap informan tersebut memiliki jabatan dan kedudukan yang tinggi serta ada beberapa informan yang sudah bekerja puluhan tahun di Bakorwil Pamekasan sehingga peneliti menganggap bahwa informan tersebut mampu memberikan data yang diharapkan oleh peneliti. 
Penelitian ini dilakukan di Badan Koordinasi Wilayah Pemerintahan dan Pembangunan Pamekasan, tempat penelitian sengaja dipilih dengan pertimbangan karena Berdasarkan Sasaran Kerja Pegawai (SKP) Bakorwil Pamekasan tahun 2014 bahwa belum sepenuhnya sasaran kerja tersebut dapat direalisasikan sehingga peneliti tertarik untuk menggali lebih dalam mengenai bagaimana pengembangan kompetensi para pegawai serta faktor-faktor yang mempengaruhi pengembangan kompetensi pegawai di Bakorwil.

Menurut Patton (1980:268) dalam Moleong (1998:103), analisis data adalah proses mengatur urutan data, mengorganisasikannya ke dalam suatu pola, kategori, dan satuan uraian dasar. Patton membedakannya dengan penafsiran, yaitu memberikan arti yang signifikan terhadap analisis, menjelaskan pola uraian dan mencari hubungan di antara dimensi-dimensi uraian. Langkah analisis data ini bertujuan untuk mencari dan menata data secara sistematis dari hasil catatan wawancara dan studi dokumentasi yang telah dilakukan. Analisis data dalam penelitian ini dilakukan dengan melakukan pengkajian dan penyusunan secara sistematis semua transkrip wawancara, catatan lapangan, bahan-bahan lain yang dihimpun untuk memperoleh deskripsi data secara utuh tentang fokus penelitian.

Analisis data dilakukan sejak pengumpulan data sampai data yang dirasa telah tercukupi yakni sampai mendapatkan jawaban dari rumusan masalah. Data tersebut terdiri dari catatan lapangan, komentar peneliti, gambar, foto, dokumen berupa laporan, biografi, artikel dan sebagainya, kemudian data tersebut dianalisis dengan cara mengurutkan data selanjutnya melakukan pengelompokan ke dalam sub bahasan. Proses analisis data ini dilakukan melalui tiga alur kegiatan yang berlangsung, yaitu: (1) reduksi data, (2) penyajian data dan (3) simpulan atau verifikasi.

\section{Hasil dan Pembahasan}

\section{Pengembangan kompetensi personil Bakorwil Pamekasan}

Tidak semua personil di Bakorwil Pamekasan dapat mengikuti program atau kegiatan yang bertujuan untuk menambah pengetahuan, tetapi hanya personil pilihan yang dapat mengikuti program pengembangan kompetensi, informan yang saya wawancarai yaitu kepala bidang pemerintahan bakorwil (Ts) terkait dengan peningkatan kompetensi mengungkapkan bahwa pegawai di Bakorwil rata-rata mendapat pengetahuan melalui bimbingan teknis dan rapat koordinasi.

Pengembangan kompetensi pegawai pada setiap instansi harus dilaksanakan jika instansi tersebut ingin berkembang, karena menurut Moeheriono (2009) salah satu manfaat dan keuntungan dalam pengembangan kompetensi dapat dikatakan sebagai acuan kesuksesan awal bekerja seseorang. Model kompetensi yang akurat ini akan dapat menentukan dengan tepat pengetahuan serta keterampilan apa saja yang dibutuhkan untuk keberhasilan dalam suatu pekerjaan tersebut. Apabila seseorang memegang posisi jabatan tertentu, maka harus memiliki kompetensi yang dipersyaratakan pada posisinya, niscaya ia diprediksikan akan sukses dan berhasil dalam mengemban tugas pekerjaannya.

Berdasarkan wawancara peneliti dengan sekretaris Bakorwil Pamekasan (M) menjelaskan bahwa ada kegiatan pelatihan atau pendidikan yang ditujukan kepada personel untuk menambah pengetahuan tetapi tidak semua personel dapat mengikuti kegiatan ini.

\section{Kondisi Bakorwil Pamekasan}

Sub Bagian Tata Usaha Bakorwil Pamekasan menyebutkan bahwa jumlah PNS di Bakorwil Pamekasan tahun 2015 sebanyak 44 orang dengan perincian yaitu pendidikan terakhir S3 sebanyak 1 orang, S2 sebanyak 7 orang, S1 sebanyak 12 orang, D3 sebanyak 2 orang, SLTA sebanyak 20 orang dan SD sebanyak 2 orang. 
Tabel 1.

Tingkat pendidikan dan jumah pegawai

\begin{tabular}{lll}
\hline No. & Pendidikan & Jumlah Pegawai \\
\hline 1. & S3 & 1 orang \\
2. & S2 & 7 orang \\
3. & S1 & 12 orang \\
4. & D3 & 2 orang \\
5. & SLTA & 20 orang \\
6. & SD & 2 orang \\
& Jumlah Total & $\mathbf{4 4}$ orang \\
\hline
\end{tabular}

Sumber: Sub Bagian Tata Usaha Bakorwil Pamekasan Tahun 2015

Dari data di atas dapat diidentifikasi bahwa pegawai di Bakorwil Pamekasan masih banyak yang berpendidikan terakhir SLTA yaitu sebanyak 20 orang. Padahal tujuan dari pendidikan adalah perubahan perilaku yang diharapkan, dengan kata lain meningkatnya kemampuan dalam melaksanakan tugas atau pekerjaan menurut Notoatmodjo (2009) pada dasarnya tujuan pendidikan adalah suatu deskripsi dari pengetahuan, sikap, tindakan, penampilan dan sebagainya yang diharapkan akan dimiliki sasaran pelatihan pada periode tertentu. Suatu lembaga pendidikan terutama pendidikan formal sebenarnya diharapkan tentang tingkat dan jenis kemampuan sasaran pendidikan atau pelatihan, antara lain perubahan pengetahuan, sikap dan kemampuan mereka.

\section{Kompetensi minimal pegawai Bakorwil Pamekasan}

Penelitian ini membahas dua faktor yang terkait dengan kompetensi minimal (threshold competencies) pegawai dalam melaksanakan tugas pokok dan fungsinya. Kedua faktor tersebut adalah pengetahuan (knowledge) dan keterampilan (skill) dari pegawai Bakorwil Pamekasan. Menurut Spencer dan Spencer (1993:15) threshold competencies adalah karakteristik utama (biasanya berupa pengetahuan atau keahlian dasar misalnya kemampuan untuk membaca) yang harus dimiliki oleh seseorang agar dapat melaksanakan pekerjaannya. Kompetensi SDM yang diperlukan untuk menghadapi tantangan baru dan jenis-jenis organisasi di tempat kerja, dapat diperoleh dengan pemahaman ciri-ciri yang kita cari dari orang-orang yang bekerja dalam organisasi-organisasi tersebut. Konsep dasar standar kompetensi ditinjau dari epistemologi, standar kompetensi terbuka atas dua kosa kata yaitu standar dan kompetensi. Standar diartikan sebagai ukuran yang disepakati sedangkan kompetensi diartikan sebagai kemampuan melaksanakan tugas-tugas ditempat kerja yang mencakup penerapan keterampilan yang didukung dengan pengetahuan dan kemampuan sesuai dengan kondisi yang dipersyaratkan (Subaedi 2010).

\section{Pengetahuan (knowledge)}

Untuk mengetahui pengetahuan (knowledge) pegawai Bakorwil Pamekasan, peneliti mengajukan beberapa pertanyaan yang berkaitan dengan pengetahuan informan mengenai tugas pokok dan fungsi, program kerja, serta tahapan dalam melakukan tugasnya. Berdasarkan hasil wawancara kepada informan mengenai pengetahuan yang terkait dengan tugas pokok dan fungsinya, rata-rata belum bisa menjawab secara tepat sesuai tupoksi berdasarkan peraturan daerah Gubernur Jawa Timur Nomor 12 Tahun 2008. Seperti petikan wawancara yang diungkapkan informan (Ts) sebagai kepala bidang pemerintahan berikut:

P: 'Apa yang Bapak ketahui mengenai tugas pokok seorang Kepala Bidang Pemerintahan Bakorwil'?

$T_{s}$ : 'Merencanakan dan melaksanakan program kerja yang sudah dirapatkan sebelumnya, kemudian laporan kepada kepala badan.'

P: 'Apa yang Bapak ketahui mengenai fungsi pegawai Kepala Bidang Pemerintahan Bakorwil'? 
Ts: 'Fungsinya membantu tugas-tugas kepala badan dalam melaksanakan kegiatan sesuai dengan tupoksi bakorwil.'

Tugas dan fungsi Kepala Bidang Pemerintahan sesuai peraturan daerah Gubernur Jawa Timur adalah merencanakan, mengkoordinasikan, memfasilitasi monitoring dan evaluasi terhadap pelaksanaan tugas pemerintahan umum, tugas dekonsentrasi dan tugas pembantuan serta otonomi daerah dan fungsinya antara lain a.) pelaksanaan penyusunan rencana kegiatan koordinasi, fasilitasi monitoring dan evaluasi terhadap tugas pemerintahan umum, tugas dekonsentrasi dan tugas pembantuan serta otonomi daerah, b.) pelaksanaan koordinasi, pembinaan, fasilitasi, monitoring dan evaluasi terhadap pelaksanaan tugas pemerintahan umum, tugas dekonsentrasi dan tugas pembantuan serta otonomi daerah, c.) pelaksanaan inventarisasi permasalahan di bidang pemerintahan umum, tugas dekonsentrasi dan tugas pembantuan serta otonomi daerah dan memfasilitasi perumusan penyelesaiannya, serta d.) pelaksanaan tugas-tugas lain yang diberikan oleh kepala badan.

\section{Keterampilan (skill)}

Untuk mengetahui keterampilan (skill) pegawai Bakorwil Pamekasan, peneliti mengajukan beberapa pertanyaan yang berkaitan dengan keterampilan informan terkait dengan tugas pokok dan fungsinya, dari hasil wawancara dengan informan didapat beragam jawaban. Seperti yang diungkapkan informan (Mi) sebagai Kepala Bidang Kemasyarakatan yang mengatakan bahwa keterampilan yang harus dimiliki sebagai Kepala Bidang Kemasyarakatan adalah wawasan dan pengetahuan tentang pemberdayaan masyarakat, berikut petikan wawancaranya:
P: Menurut Bapak keterampilan apa yang wajib dimiliki seorang Kepala Bidang Kemasyarakatan terkait dengan tugas pokoknya?
Mi: Wawasan dan pengetahuan tentang pemberdayaan masyarakat dan permasalahan- permasalahan apa yang terjadi di wilayah kerja serta solusi yang tepat untuk meminimalisasi permasalahan tersebut.

Serta jawaban dari informan (Ts) sebagai Kepala Bidang Pemerintahan yang mengatakan bahwa keterampilan yang wajib dimiliki Kepala Bidang Pemerintahan adalah pendidikan dan pelatihan pimpinan tiga sesuai dengan jabatan eselon tiga, berikut petikan wawancaranya:

\footnotetext{
P: Menurut Bapak keterampilan apa yang wajib dimiliki seorang pegawai Kepala Bidang Pemerintahan terkait dengan tugas pokoknya?

Ts: Yang pasti diklat pim 3 sesuai jabatan eselon III dan perlu ada keterampilan lain yang harus diberikan oleh pemerintah provinsi tentang ilmu pemerintahan sesuai dengan bidang saya.
}

Selanjutnya jawaban yang lebih spesifik terkait dengan keterampilan (skill) yang harus dimiliki pegawai Bakorwil menurut informan (M) adalah menyusun, mengelola dan mengevaluasi program dan kinerja, mengembangkan SDA, mengelola keuangan, merumuskan konsep-konsep naskah dinas, mengelola informasi, dan mengelola kehumasan. Berikut petikan wawancara selengkapnya:

P: Menurut Bapak keterampilan seperti apa yang wajib dimiliki seorang Sekretaris Bakorwil terkait dengan tugas pokoknya?

M: Keterampilan yang harus dimiliki Sekretaris adalah keterampilan dalam menyusun, mengelola, mengevaluasi program dan kinerja, mengembangkan sumber daya aparatur, mengelola keuangan dan aset, merumuskan konsep-konsep naskah dinas, kearsipan dan kepustakaan, mengelola informasi, dokumentasi, mengelola kehumasan, keprotokolan dan kerumahtanggaan.

Menurut Spencer dan Spencer (1993), keterampilan (skill) merupakan kemampuan yang dimiliki seseorang untuk melaksanakan tugas tertentu baik secara fisik maupun mental, apabila hal ini dikaitkan dengan jawaban dari para informan terkait dengan pemahaman keterampilan (skill), maka 
dapat diidentifikasi tugas pokok dan fungsi pegawai belum berjalan dengan baik karena rata-rata jawaban dari informan belum spesifik. Hal ini juga dibuktikan dengan Sasaran Kerja Pegawai (SKP) dari staf bidang kemasyarakatan Bakorwil Pamekasan yang mana kegiatan tugas jabatannya belum mencapai target, berikut tabel SKP dari staf (Rf) tahun 2014.

Tabel 2.

Capaian sasaran kerja staf bidang kemasyarakatan

\begin{tabular}{|c|c|c|c|c|c|c|}
\hline \multirow{2}{*}{ No } & \multirow{2}{*}{ Kegiatan tugas jabatan } & \multicolumn{5}{|l|}{ Realisasi } \\
\hline & & $\begin{array}{l}\text { Kuant } \\
\text { output }\end{array}$ & $\begin{array}{l}\text { Kual } \\
\text { mutu }\end{array}$ & I & $\begin{array}{l}\text { Kuant } \\
\text { output }\end{array}$ & $\begin{array}{l}\text { Kual } \\
\text { mutu }\end{array}$ \\
\hline 1. & $\begin{array}{l}\text { Mengetik administrasi persiapan kegiatan rapat } \\
\text { koordinasi dan monitoring PMKS, PUG, JKN } \\
\text { dan Raskin }\end{array}$ & 288 berkas & 100 & & 283 berkas & 80 \\
\hline 2. & $\begin{array}{l}\text { Mengetik notulen dan laporan rapat koordinasi } \\
\text { PMKS, PUG, JKN dan Raskin }\end{array}$ & 8 dokumen & 100 & & 6 dokumen & 85 \\
\hline 3. & $\begin{array}{l}\text { Mengetik laporan kegiatan monitoring PMKS, } \\
\text { PUG, JKN dan Raskin }\end{array}$ & 4 laporan & 100 & & 3 laporan & 90 \\
\hline
\end{tabular}

Sumber: Sub Bagian Tata Usaha Bakorwil Pamekasan tahun 2014

Dari tabel SKP di atas disebutkan bahwa tiga kegiatan tugas jabatan dari staf (Rf) yakni: (1) mengetik administrasi persiapan kegiatan rapat koordinasi dan monitoring PMKS, PUG, JKN dan Raskin dengan target 288 berkas sedangkan yang terealisasi hanya 283 berkas, (2) mengetik notulen dan laporan rapat koordinasi PMKS, PUG, JKN dan Raskin dengan target 8 dokumen, hanya terealisasi 6 dokumen, serta (3) Mengetik laporan kegiatan monitoring PMKS, PUG, JKN dan Raskin dengan target 4 laporan hanya 3 yang terealisasikan.

Padahal secara rinci Moeheriono (2009) memaparkan lima dimensi kompetensi terkait dengan keterampilan (skill) yang harus dimiliki oleh pegawai yaitu task skill, adalah keterampilan untuk melaksanakan tugas-tugas rutin sesuai dengan standar di tempat kerja, task management skill, adalah keterampilan untuk mengelola serangkaian tugas yang berbeda yang muncul dalam pekerjaan, contingency management skill, adalah keterampilan mengambil tindakan yang cepat dan tepat bila timbul suatu masalah dalam pekerjaan, job role environment skill, adalah keterampilan untuk bekerja sama serta memelihara kenyamanan lingkungan kerja, transfer skill, adalah keterampilan untuk beradaptasi dengan lingkungan kerja baru.

\section{Model kompetensi yang lama}

Model kompetensi yang digunakan oleh Badan Koordinasi Wilayah Pemerintahan dan Pembangunan Pamekasan berpatokan pada visi dan misi Badan Koordinasi Wilayah Pemerintahan dan Pembangunan Pamekasan yang kemudian diimplementasikan ke dalam tugas pokok dan fungsi instansi. Dari tugas pokok dan fungsi Bakorwil tersebut, kemudian dirancang dalam programprogram kerja masing-masing jabatan.

\section{Model pengembangan kompetensi yang baru}

Pada bagian ini penulis membuat model rencana untuk mengembangkan kompetensi pegawai pada Badan Koordinasi Wilayah Pemerintahan dan Pembangunan Pamekasan. Model pengembangan kompetensi pada Badan Koordinasi Wilayah Pemerintahan dan pembangunan Pamekasan terdiri dari dua kompetensi yang tampak (tangiable competency) yaitu pengetahuan (knowledge) dan 
keterampilan (skill) yang dibutuhkan oleh pegawai, karena menurut Sanghi (2007) bahwa kompetensi dari aspek pengetahuan dan keahlian cenderung lebih nyata atau nampak (visible) dan relatif berada di permukaan sebagai salah satu karakteristik yang dimiliki manusia, sedangkan konsep diri, watak dan motif kompetensi lebih tersembunyi (hidden) berada di dalam dan berada pada titik sentral kepribadian seseorang sehingga lebih sulit untuk dikembangkan.

Penulis menggunakan model organisasi pembelajaran (model learning organization) dari Senge, Ross, Smith \& Kleiner (2001: 60-61) dalam Yuniarsih dan Suwatno (2008) di mana organisasi pembelajaran merupakan suatu kegiatan berorganisasi lazimnya dalam bentuk kelompok untuk meningkatkan penguasaan ilmu, keterampilan, profesionalisme dan bidang-bidang lainnya yang sifatnya berkelanjutan. Pengorganisasian organisasi pembelajaran yang melibatkan semua disiplin pembelajaran yang berkelanjutan, terdiri dari gagasan penuntun, teori, metode dan alat-alat serta inovasi dalam infrastruktur.

Maka dari itu, penulis mencoba untuk mengaplikasikan model di atas dalam mengembangkan kompetensi pegawai Bakorwil Pamekasan yang digambarkan secara sederhana sebagai berikut

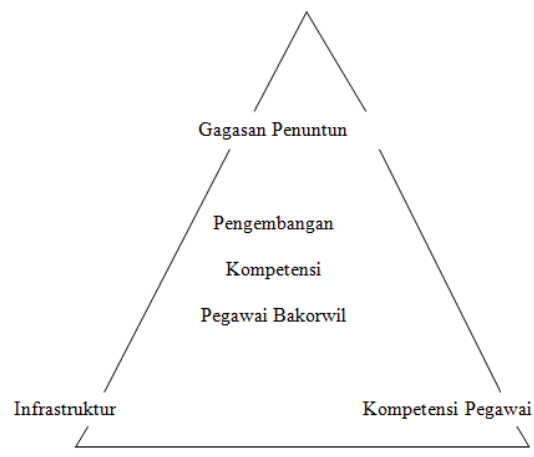

Gambar 1.

Pengembangan Kompetensi Pegawai Bakorwil Pamekasan Berdasarkan pada Model Organisasi Pembelajaran (Model Learning Organization).

Sumber: Sange, Ross, Smith, Kleimer (2001:28) dalam Yuniarsih \& Suwatno (2008:46). Dari gambar segitiga (integritas) di atas, dapat dijelaskan bahwa untuk mengembangkan kompetensi pegawai Bakorwil Pamekasan, harus berfokus pada tiga unsur, yaitu: gagasan penuntun, kompetensi pegawai serta infrastruktur.

Gagasan penuntun tersebut berisi tujuan mengapa dilakukan pengembangan kompetensi pegawai. Gagasan penuntun harus jelas sehingga menimbulkan keinginan dan gairah dari semua yang berpartisipasi di dalamnya untuk menjadi lebih unggul yang berdasar pada visi misi Bakorwil Pamekasan. Maka dari itu, gagasan penuntun di atas adalah untuk meningkatkan koordinasi serta mewujudkan sinergi penyelenggaraan pemerintah dan pembangunan Provinsi Jawa Timur. Di samping itu, tugas pokok dan fungsi dari Bakorwil Pamekasan juga menjadi isi dari gagasan penuntun pada gambar segitiga di atas.

Kompetensi pegawai merupakan serangkaian kompetensi yang diperlukan untuk menghasilkan kinerja yang unggul dalam melakukan koordinasi baik dalam lingkungan Pemerintah Provinsi maupun dengan Kabupaten/Kota. Mengingat penelitian ini menggunakan kompetensi dari aspek pengetahuan dan keterampilan maka, aspek pengetahuan (knowledge) tersebut meliputi: a.) analytical thinking, yaitu kemampuan memahami situasi dengan cara memandang sebagai suatu kesatuan yang mendasar, b.) conceptual thinking, yaitu kemampuan mengidentifikasi permasalahan utama yang mendasar dalam situasi yang komplek, c.) expertise, penguasaan pengetahuan untuk menggunakan dan mendistribusikan pengetahuan tersebut. Serta aspek keterampilan (skill) yang meliputi: a.) achievment 
orientation, yaitu penilaian yang menekankan kepada hasil pekerjaan yang lebih baik, b.) concern for order, yaitu dimensi ini merupakan pemicu utama yang dapat mereduksi ketidakpastian lingkungan dengan memonitor dan memeriksa pekerjaan, c.) initiative, yaitu preferensi untuk mengambil suatu tindakan yang dicerminkan dengan melakukan lebih yang diperlukan dalam pekerjaan, d.) information seeking, keingintahuan yang mendasar untuk lebih mengetahui tentang sesuatu.

Infrastruktur berisi dukungan sumber daya, sehingga pengembangan kompetensi dapat berjalan lancar. Dukungan sumber daya tersebut meliputi: a.) dukungan pimpinan, artinya dukungan dari kepala badan dan jajaran kepala bidang berupa kegiatan untuk mengadakan pendidikan dan pelatihan terhadap personil Bakorwil yang bertujuan untuk mengembangkan personilnya, b.) dana, menyediakan dana yang ditujukan untuk mengikutsertakan personilnya melaksanakan kegiatan diklatdiklat pengembangan kompetensi, c.) informasi, mencari informasi yang berkaitan dengan kegiatankegiatan yang berhubungan dengan peningkatan kompetensi. d.) para pendukung (pakar, praktisi, mitra), yaitu mengundang para ahli atau praktisi untuk menambah wawasan keahlian atau keterampilan personil dalam bentuk seminar atau bimbingan teknis. e.) komunikasi, adanya komunikasi antara atasan dengan bawahan yang intens dalam rangka kegiatan pengembangan kompetensi, f.) transportasi serta akomodasi, tersedianya fasilitas berupa alat transportasi yang memadai mengingat kegiatan Bakorwil Pamekasan yang selalu melaksanakan monitoring ke daerahdaerah.

Model kompetensi umum untuk pegawai Bakorwil Pamekasan yang baru ini mengacu pada model kompetensi umum dari Spencer \& Spencer (1993) serta visi misi Bakorwil Pamekasan. Susunan kompetensi umum yang mendekati tugas pokok dan fungsi personil Bakorwil Pamekasan serta Key Performance Indicator adalah seperti pada Tabel 3.

Tabel 3.

Kompetensi umum dan key performance indicator personil Bakorwil Pamekasan menurut kamus kompetensi Spencer \& Spencer

\begin{tabular}{|lll|}
\hline No & Jenis tugas & Jenis kompetensi dan definisi \\
\hline 1. & Melaksanakan & Berpikir konseptual (conceptual thinking, \\
& koordinasi & $C T)$ : \\
& & Kemampuan memahami situasi dengan cara \\
& memandang sebagai satu kesatuan yang \\
& & intrigitas dan mencakup kemampuan \\
& & mengidentifikasi
\end{tabular}

Berpikir analitis (analytical thinking, AT): Kemampuan untuk memahami situasi dengan cara memecahkannya menjadi bagian-bagian yang lebih rinci serta mengamati keadaan tahap demi tahap
Key Performance Indicators

- Membuat perumusan kebijakan teknis sesuai lingkup tugasnya

- Mengelola kegiatan administrasi umum, kepegawaian dan keuangan

- Menyusun rencana

- kegiatan koordinasi terhadap tugas pemerintahan umum

- Membuat rencana koordinasi terhadap pembangunan ekonomi

- Merencanakan koordinasi terhadap upaya peningkatan kesejahteraan masyarakat

- Membuat rencana koordinasi terhadap pelaksanaan pembangunan di bidang sarana dan prasarana

- Pemberian dukungan atas penyelenggaraan pemerintah di wilayah kerja

- Melakukan pengelolaan penyunan program, anggaran dan perundangundangan

- Melakukan penyusunan rencana kegiatan koordinasi dan tugas dekonsentrasi

- Memberi evaluasi terhadap 
Keahlian teknikal/profesional/manajerial (expertise, EXP): Penguasaan bidang pengetahuan terkait dengan pekerjaan dan motivasi untuk menggunakan, mengembangkan dan membagikan pengetahuan yang terkait dengan pekerjaan kepada orang lain pelaksanaan pembangunan ekonomi - Mengevaluasi pelaksanaan upaya peningkatan kesejahteraan masyarakat

- Mengevaluasi pelaksanaan pembangunan di bidang sarana dan prasarana

- Pembinaan dan pelaksanaan tugas - Melaksanakan koordinasi penyusunan program, anggaran dan penyelenggaraan tugas-tugas bidang

- Melaksanakan inventarisasi permasalahan di bidang pemerintahan umum

- Melaksanakan koordinasi dan pembinaan dalam bidang perkebunan, pertanian, peternakan, perikanan kelautan, industri perdagangan, koperasi, pengusaha kecil menengah, BUMD, pajak bumi dan bangunan, perhubungan, serta pengembangan dunia usaha

- Melaksanakan inventarisasi permasalahan di bidang kemasyarakatan

- Inventarisasi permasalahan di bidang sarana dan prasarana serta memfasilitasi penyelesaiannya

Melaksanakan fasilitasi, monitoring dan pembinaan terhadap pelaksanaan tugas pemerintahan umum secara cermat

Melaksanakan pembinaan, fasilitasi dan monitoring terhadap bidang pertanian, perkebunan, kehutanan, peternakan, perikanan kelautan, industri perdagangan, koperasi, BUMD, pendapatan asli daerah, pajak bumi dan bangunan, perhubungan serta pengembangan dunia usaha

Proaktif (initiative, INT): Dorongan bertindak untuk melebihi yang dibutuhkan oleh pekerjaan, tindakan ini dilakukan untuk meningkatkan hasil pekerjaan atau menciptakan peluang baru

Mencari informasi (information seeking, INFO): Besarnya usaha tambahan yang dilakukan untuk mencari informasi lebih banyak yang berhubungan dengan pekerjaan

Sumber: Kamus Spencer \& Spencer (1993) dan hasil analisis
Melaksanakan pemberian rekomendasi usulan program pembangunan yang diusulkanoleh Kabupaten/Kota

Usaha yang dilakukan untuk mencari informasi tentang tugas-tugas lain yang diberikan Gubernur atau Kepala Badan 


\section{Faktor yang mempengaruhi pengembangan kompetensi Personil Bakorwil Pamekasan}

Faktor yang mempengaruhi pengembangan kompetensi personil Bakorwil Pamekasan adalah penempatan personil yang tidak sesuai dengan tugas pekerjaannya sehingga perlu membutuhkan lebih banyak waktu, tenaga dan biaya yang harus dikeluarkan untuk mengembangkan personel seperti ini. Hal ini berkaitan dengan pernyataan Zwell (2000) dalam Sudarmanto (2009) bahwa salah satu faktor yang mempengaruhi kompetensi adalah kapasitas intelektual, kapasitas intelektual ini akan berpengaruh terhadap penguasaan kompetensi, kompetensi ini tergantung pada kemampuan berfikir secara konseptual dan berpikir analitis, dalam pengambilan pegawai seharusnya seorang perekrut berpikir secara analitis untuk kedepannya demi kinerja instansi.

Faktor selanjutnya yang menghambat pengembangan kompetensi adalah sistem birokrasi yang masih sangat kental serta adanya pembatasan keikutsertaan personil dalam pelatihan. Hal ini berkaitan dengan pandangan Zwell (2000) dalam Sudarmanto (2009) bahwa kepercayaan dan nilai seseorang terhadap sesuatu sangat berpengaruh terhadap sikap dan perilaku seseorang, seseorang yang memiliki nilai dan kepercyaan diri tidak kreatif cenderung tidak berpikir untuk menemukan sesuatu yang baru dan menantang. Seperti pernyataan yang diungkapkan informan (Mi) sebagai kepala bidang kemasyarakatan berikut:

Mi: 'menurut saya yang paling mempengaruhi itu adalah birokrasi yang masih sangat kental dan adanya pembatasan keikutsertaan personil dalam pelatihan.'

Kemudian faktor yang lainnya adalah minimnya dana, minimnya kualitas personal, mentalitas personil serta minimnya diklat-diklat yang diselenggarakan oleh badan diklat Provinsi Jatim, seperti yang dijelaskan oleh informan (M) sebagai sekretaris Bakorwil Pamekasan dalam petikan wawancara berikut:

M: 'Hambatan yang dihadapi dalam pengembangan kompetensi antara lain minimnya diklatdiklat khususnya diklat-diklat teknis yang diselenggarakan oleh Badan Diklat Provinsi Jawa Timur sebagai satu-satunya lembaga yang diberi kewenangan untuk menyelenggarakan diklat pegawai Pemprov Jatim. Minimnya pendanaan, sehingga tidak mampu untuk mengirimkan personil mengikuti diklat-diklat peningkatan kompetensi bidang yang dilaksanakan oleh lembaga lain yang swadaya maupun untuk melaksanakan inhouse-inhouse training maupun bimbingan-bimbingan teknis. Kualitas personil yang sebagian besar tidak mendukung sepenuhnya terhadap peningkatan SDM, hal ini terkait dengan kualitas aparatur saat rekruitmen pegawai masa lalu yang berasal dari pengganti pensiun maupun pengangkatan melalui honorer yang tidak melalui seleksi kompetensinya. Mentalitas personil yang sulit untuk ditingkatkan kompetensinya khususnya untuk mendukung pencapaian kinerja karena terkiat dengan kualitasnya yang kurang memadai dan usia yang sudah tidak produktif serta pengalaman-pengalaman sebelumnya tidak memerlukan kompetensi dalam pengangkatan jabatan.'

Hal ini berkaitan dengan ungkapan Zwell (2000) dalam Sudarmanto (2009) bahwa karakteristik personal, keahlian dan isu-isu emosional merupakan faktor yang mempengaruhi pengembangan kompetensi seseorang. Ketakutan membuat kesalahan, perasaan malu, perasaan tidak suka, selalu berpikir negatif, pengalaman masa lalu yang selalu negatif sangat berpengaruh terhadap penguasaan kompetensi seseorang. Dengan tidak mengikuti diklat-diklat peningkatan kompetensi bidang karena terbatasnya dana maka, personil tidak memiliki keahlian yang berkaitan dengan tugasnya. Padahal tujuan memperbaiki kemampuan di bidangnya melalui diklat-diklat adalah meningkatkan kecakapan kompetensinya. Karakteristik personal seseorang juga turut berpengaruh terhadap kompetensi seseorang, kompetensi membangun hubungan dan komunikasi dengan tim kerja dari orang yang memiliki sifat introvert akan berbeda dengan orang yang bersifat ekstrovert. 


\section{Simpulan}

Pengembangan kompetensi yang dilakukan terhadap personil Bakorwil Pamekasan masih sebatas pada mengikuti rapat kerja, rapat teknis, kongres, seminar, bimbingan teknis dan workshop. Sedangkan pengetahuan (knowledge) minimal personil Bakorwil Pamekasan yang berkaitan dengan tupoksi, program kerja dan tahapan-tahapan dalam melaksanakan program kerja tidak semua personil memahaminya sedangkan untuk keterampilan (skill) personil Bakorwil Pamekasan yang harus dimiliki adalah kemampuan menyusun, mengelola, mengevaluasi program dan kinerja, mengelola keuangan dan aset, kemampuan berkomunikasi, kemampuan beradaptasi serta mengelola kearsipan dan informasi.

Faktor-faktor yang dihadapi dalam pengembangan kompetensi personil Bakorwil Pamekasan antara lain: Kepercayaan dan nilai, Keahlian/keterampilan, Pengalaman, Karakteristik personal, Motivasi, Isu-isu emosional, Kapasitas intelektual. Pengembangan kompetensi personil Bakorwil Pamekasan yang baru memberikan petunjuk dalam menunjang tugas pokok dan fungsinya.

\section{Daftar Pustaka}

Emmyah (2009) Pengaruh kompetesi terhadap kinerja pegawai pada politeknik negeri Ujungpandang. Thesis, Sekolah Tinggi Ilmu Administrasi Negara, Makassar.

Moeheriono (2009) Pengukuran kinerja berbasis kompetensi. Bogor: Ghalia Indonesia.

Moleong LJ (1998) Metodologi penelitian kualitatif. Bandung: PT Remaja Rosdakarya.

Muhyi (2009) Analisis faktor-faktor yang mempengaruhi efektivitas organisasi. (Studi tentang Pengaruh Kualitas Sumber Daya Manusia, Struktur Organisasi, Kewenangan, Keuangan dan Sarana prasarana terhadap Efektifitas Badan Koordinasi Wilayah Pemerintahan dan Pembangunan Pamekasan). Thesis, Universitas 17 Agustus 1945, Surabaya.

Notoatmodjo S (2009) Pengembangan sumber daya manusia. Jakarta: PT Rineka Cipta.

Sanghi S (2007) The Handbook of competency mapping understanding, designing and implementing competency models in organizations. New Delhi: Vivek Mehra for Sage Publications India.

Subaedi A (2010) Kompetensi SDM UKM dan pengaruhnya terhadap kinerja UKM di Surabaya. Surabaya: Fakultas Ekonomi Universitas 17 Agustus 1945.

Sudarmanto (2009) Kinerja dan pengembangan kompetensi SDM teori, dimensi pengukuran dan implementasi dalam organisasi. Yogyakarta: Pustaka Pelajar.

Sugiyono (2010) Metode penelitian pendidikan pendekatan kuantitatif dan kualitatif dan R\&D. Bandung: Alfabeta.

Spencer SM dan Spencer LM.(1993).Competence at work model for superior performance. Canada: Library of Congress Cataloging.

Yuniarsih T dan Suwatno (2008) Manajemen sumber daya manusia teori, aplikasi dan isu Penelitian. Bandung: Alfabeta.

Zwell M (2000) Creating a culture of competence. New York: John Wiley \& Sons. 